\title{
Analisisis Pengaruh Berbagai Variabel Terhadap Kewirausahaan Anggota Kelompok Ternak Binaan Putkati di Sulawesi Selatan
}

\author{
Analysis of the Influence of Various Variables on the Entrepreneurship of \\ Members of the Putkati Guided Livestock Group in South Sulawesi
}

\author{
Andi Mulia ${ }^{1}$ Andi Suarda ${ }^{2 *}$, \\ ${ }^{1}$ Fakultas Ekonomi dan Bisnis Islam \\ Universitas Islam Negeri (UIN) Alauddin Makassar \\ 2Jurusan Ilmu Peternakan Fakultas Sains dan Teknologi \\ Universitas Islam Negeri (UIN) Alauddin Makassar \\ *Korespondensi Email: etta.adda@yahoo.com
}

\begin{abstract}
ABSTRAK
Penelitian ini bertujuan untuk menguji kompentensi pengaruh berbagai variabel terhadap Kewirausahaan Anggota kelompok Ternak Binaan Putkati di Sul-Sel, dengan menganalysis dan mengetahui: pengaruh bantuan ternak, pendampingan serta budaya kebersamaan terhadap perilaku anggota. Penelitian ini dilaksanakan pada 4 Kabupaten di sulawesi Selatan yaitu Kab. bulukumba, Kab. Polmas, Kab. Mamuju dan Kab. Luwu. Metode yang digunakan dalam penelitian ini adalah survei lapangan dengan menggunakan kuesoiner dan wawancara langsung 80 kelompok ternak atau sebanyak 320 petani peternak binaan Proyek Putkati di Sulsel sebagai responden. Pengambilan sampel dilakukan secara proporsional sesuai dengan banyaknya jenis kelompok ternakpada setiap kabupaten, kemudian dilanjutkan dengan pengambilan sampel acak sederhana di 4 kabupaten sebagai lokasi proyek dan sekaligus lokasi penelitian. Data dianalysis dengan menggunakan Statistik Path Analysis untuk mengetahui besarnya pengaruh masing-masing variabel dalam penelitian ini. Hasil menunjukkan bahwa; bantuan ternak, pendampingan dan budaya kebersamaan berpengaruh terhadap kewirausahaan anggota kelompok ternak binaan Putkati di Sulawesi Selatan. Sedangkan kontribusi terbesar pada pendampingan sebesar $23,5 \%$.
\end{abstract}

Kata kunci : Putkati, Ternak, Kewirausahaan Anggota Kelompok

\begin{abstract}
Analysis of the varians variables influence to the members entrepreneurship of livestock group of Putkati founding in South Sulawesi. (supervised by Ahmad Ramadhan Siregar, Palmarudi and Syamsuddin Hasan). This research aims to test the competence of influence of the varians variables for levestock group maturity of Putkati Founding in South Sulawesi with analizing and knowing : The influence of livestock did, assistance, and togetherness costum to the members entrepreneurship of group. This investigation was curried out in South Sulawesi in four regencies namely bulukumba, Polmas, Mamuju and Luwu regeney. The method which was used in this reseach was field surveying by using questionaire and interview for 80 livestock group or as to 320 animal
\end{abstract}


husbandry farmers of Putkati project founding in South Sulawesi as respondents. The taken sample was done rasionably and in accordance with quantity of the various of livestock group in each regencies and then it was simply taken at random in four regeneics as project location and so was research location. The data was analyzed by using Statistik Path Analysis to know the significant influence of each variables in this research. The result shuwed that : The livestock did, assistance and togetherness culture were influenced to the members entrepreneourship of livestock group of Putkati founding in South Sulawesi. Mean while the bigger countribution to assistance was 23,5\%.

Keywords: Putkati, Livestock, Entrepreneurship of group.

\section{PENDAHULUAN}

Kewirausahaan berasal dari istilah bahasa Prancis Enterprendre yang berarti memulai sesuatu. Istilah ini pertama kali dicetuskan oleh Richard Cantillon pada abad ke 18 yang menyatakan bahwa kewirausahaan terkait dengan mengambil resiko karena membeli pada suatu harga tertentu dan menjualnya pada harga yang tidak tentu. Para ahli ekonomi yang mendefinisikan kewirausahaan atas dasar fungsi ekonomi, selanjutnya para ahli psikologi memberikan definisi kewirausahaan dengan menfokuskannya pada kepribadian dari individu wirausaha.

Teori ini berusaha untuk mengidentifikasi dan mengukur sifat-sifat kepribadian dari para wirausaha dan menyoroti sejumlah faktor yang mencirikan kewirausahaan. Sedang karakteristik diantara wirausaha berkenaan dengan kebutuhannya untuk berprestasi. Para ahli di bidang psikologi sosial mendefinisikan faktor-faktor eksternal yang bertindak sebagai potensi stimulan untuk aktivitas kewirausahaan dalam kelompok ternak binaan Putkati di Sul-Sel adalah menempatkan kewirausahaan didalam lingkungan sosial yang luas, guna mengetahui pengaruh dari sejumlah faktor-faktor sosial terhadap keinginan dari seseorang individu untuk berprilaku kewirausahaan. Keputusan seseorang individu untuk memulai meniti karier kewirausahaan selain dipengaruhi oleh lingkungan juga dipengaruhi oleh faktor pribadi. Faktor lingkungan tersebut dapat berasal dari lingkungan budaya, kebijakan pemerintah, ketidakpuasan terhadap kariernya pada organisasi tradisional, tidak memiliki akses untuk bekerja pada perusahaan, tersedianya sumber informasi, tersedianya sumber daya infra struktur seperti tempat usaha yang murah, perhatian media massa dan tersedianya teknologi. Sedangkan faktor pribadi yang mendorong timbulnya aktivitas kewirausahaan adalah tersedianya sumberdaya keuangan, keinginan untuk aktualisasi diri, dukungan keluarga, dan pengalaman yang relevan. Sedangkan latar belakang keluarga dan 
sosial, pendidikan, kepercayaan, budaya, pengalaman hidup merupakan faktor yang berperan dalam mendorong seorang invidu untuk menjadi wirausaha.

Untuk memahami wirausaha dan kewirausahaan diuraikan dalam teori pendekatan perilaku. Teori ini memfokuskan pada pengertian bagaimana sikap dan perilaku, keahlian dan keterampilan manajemen, pengalaman masa lalu, dan sebagainya yang dipengaruhi oleh kualitas kewirausahaan seseorang atau anggota kelompok. Para ahli dibidang ini menyatakan bahwa para wirausaha anggota kelompok yang berhasil memiliki sejumlah perilaku dan sikap yaitu memiliki keyakinan pribadi untuk bekerja secara berkelompok dan mandiri, bekerja keras, memahami bahwa pengambilan resiko adalah bahagian dari keberhasilan, bertanggung jawab atas hasil yang diperoleh (baik atau buruk), kreatif dan menyukai tantangan serta mampu mengendalikan potensi peluang yang lebih baik dibandingkan kebanyakan orang, memiliki kepekaan terhadap keadaan yang mendesak (sense of urgency) yang menjadikannya berorientasi tindakan, memilikim pengetahuan yang luas mengenai faktor-faktor yang diperlukan untuk berhasil, mampu mencari bantuan dari pihak luar untuk melengkapi keterampilan, pengetahuan dan kemampuannya kemudian mampu mengambil resiko mederat, keinginan untuk bersaing, mampu untuk memacahkan masalah secara kreatif, memiliki komitmen terhadap kelompoknya, berorientasi tujuan, optimisme, realitas dan bertanggung jawab, berinisiatif, antusias dan tidak mudah menyerah terutama bila kondisi kelompoknya menurun, menyukai belajar dari kelompoknya, optimistik, dan sangat energik.

Menurut Chaplin (1968) mengatakan bahwa intensif berupa bantuan diarahkan sebagai suatu obyek eksternal yang cenderum membangkitkan motivasi dan menegakkan tingkah laku menuju pada sasaran. Melakukan kegiatan dalam kelompok selain memiliki kepercayaan diri, keinginan untuk belajar (Kwok dan See Ngoh, 1995) memilki komitmen terhadap tugas, juga berorientasi efisien, perhatian pada kualitas kerja.

Menurut Anonim (2002) mengatakan bahwa hal-hal yang perlu difasilitasi oleh pendamping dalam membantu anggota kelompok mengembangkan usahanya yaitu : a) bimbingan untuk mencapai skala usaha, b) ketersediaan agro input dan permodalan, c) teknologi tepat guna yang sesuai dengan lokalita, d) homogenitas produk, e) kualitas yang terstandardisasi, dan f) keteraturan produksi dan distribusi.

Lebih lanjut Widjaya (1986) mengatakan bahwa meskipun terjadinya modernisasi nilai kebersamaan dan norma sosial budaya lama akan tetap dapat diterima sepanjang memiliki 
keluesan dan dapat menyesuaikan diri dengan situasi dan kondisi yang selalu berubah dan berkembang. Lebih lanjut dikatakan bahwa budaya kebersamaan/ kegotongroyongan masyarakat atau anggota kelompok dapat mempengaruhi kegiatan usaha seseorang.

\section{METODE PENELITIAN}

Penelitian ini dilaksanakan di Sulawesi Selatan yaitu Kab. Bulukumba, Kab. Polmas, Kab. Mamuju dan Kab. Luwu. Metode yang digunakan dalam penelitian ini adalah survei lapangan dengan menggunakan kuesoiner dan wawancara langsung 80 kelompok ternak atau sebanyak 320 petani peternak binaan Proyek Putkati di Sulsel sebagai responden. Pengambilan sampel dilakukan secara proporsional sesuai dengan banyaknya jenis kelompok ternak pada setiap kabupaten, kemudian dilanjutkan dengan pengambilan sampel acak sederhana di 4 kabupaten sebagai lokasi proyek dan sekaligus lokasi penelitian. Data dianalysis dengan menggunakan Statistik Path Analysis untuk mengetahui besarnya pengaruh variabel, bantuan ternak, pendampingan dan budaya kebersamaan terhadap kewirausahaan anggota kelompok ternak binaan Putkati di Sulawesi Selatan.

\section{HASIL DAN PEMBAHASAN}

Bantuan ternak $\left(X_{5}\right)$, Pendampingan $\left(X_{6}\right)$ dan Budaya Kebersamaan $\left(X_{7}\right)$ adalah berpengaruh terhadap kewirausahaan anggota Kelompok $\left(\mathrm{X}_{4}\right)$. Untuk mengetahui sejauhmana ketiga variabel penyebab dapat berpengaruh terhadap Kewirausahaan anggota Kelompok $\left(\mathrm{X}_{4}\right)$, maka dilakukan uji statistik Path Analysis yang dinyatakan dalam persamaan berikut :

$$
\mathrm{X}_{4}=\mathrm{P}_{\mathrm{X} 4 \times 5} \mathrm{X}_{5}+\mathrm{P}_{\mathrm{X} 4 \mathrm{X}_{6}} \mathrm{X}_{6}+\mathrm{P}_{\mathrm{X} 4 \mathrm{X} 7} \mathrm{X}_{7}+\mathrm{P}_{\mathrm{X} 4 \mathrm{U} 4} \mathrm{U}_{4}
$$

Keterangan:

$\mathrm{X}_{4}=$ Kewirausahaan Anggota Kelompok

$\mathrm{P}_{\mathrm{X} 4 \times 5} \mathrm{X}_{5}=$ Koefisien Path dari Bantuan ternak

$\mathrm{P}_{\mathrm{X}_{46}} \mathrm{X}_{6}=$ Koefisien Path dari Pendampingan

$\mathrm{P}_{\mathrm{X} 4 \mathrm{X} 7} \mathrm{X}_{7}=$ Koefisien Path dari Budaya Kebersamaan

$\mathrm{P}_{\mathrm{X} 4 \mathrm{U} 4} \mathrm{U}_{4}=$ Koefisien Path dari Residu

Dengan Hipotesis Operasionalnya sebagai berikut $\mathrm{H}_{0}=\mathrm{P}_{\mathrm{X}_{1} \mathrm{X}}<0$, dengan $\mathrm{H}_{1}=\mathrm{P}_{\mathrm{X}_{1} \mathrm{X}}>$ $0 ; i=5,6$ dan 7 . 
Untuk membuktikan Hipotesis 4 tersebut, dilakukan analisis pada data penelitian dan hasil ujinya disajikan pada tabel 5.2.10.

Tabel tersebut menunjukkan bahwa koefisien jalur path dari hasil penelitian secara keseluruhan adalah signifikan, sehingga dapat diambil keputusan bahwa $\mathrm{H}_{0}$ ditolak dan $\mathrm{H}_{1}$ diterima, ini berarti dapat diteruskan ke pengujian secara individual. Selanjutnya hasil pengujian koefisien path secara individual, menunjukkan bahwa koefisien path dari variabel $X_{5}, X_{6}$ dan $X_{7}$, ke tiga varuabel tersebut signifikan secara statistik sehingga $H_{0}$ ditolak dan $H_{1}$ diterima, untuk lebih jelasnya dapat dilihat pada tabel dibawah ini.

Tabel 1. Hasil Uji Statistik Path Analysis Pengaruh Variabel Penyebab $X_{5}, X_{6}$ dan $X_{7}$ Tehadap Variabel $\mathrm{X}_{4}$

\begin{tabular}{cccccc}
\hline $\begin{array}{c}\text { Struktur } \\
\text { Parameter }\end{array}$ & Nilai & $\begin{array}{c}\text { Pengaruh } \\
(\%)\end{array}$ & t.hit & t.tabel & Keputusan \\
\hline $\mathrm{X}_{5}$ terhadap $\mathrm{X}_{4}$ & 0,280 & 7,840 & 2,944 & 1,967 & $\mathrm{H}_{0}$ ditolak \\
$\mathrm{X}_{6}$ terhadap $\mathrm{X}_{4}$ & 0,432 & 18,662 & 3,982 & & $\mathrm{H}_{0}$ ditolak \\
$\mathrm{X}_{7}$ terhadap $\mathrm{X}_{4}$ & 0,209 & 4,368 & 2,335 & & $\mathrm{H}_{0}$ ditolak \\
$\mathrm{R}^{2} \mathrm{X}_{4}\left(\mathrm{X}_{5}, \mathrm{X}_{6}, \mathrm{X}_{7}\right)$ & 0,462 & 46,2 & 6,697 & 3,024 & $\mathrm{H}_{0}$ ditolak \\
Residu Path & 0,538 & & & & \\
\hline
\end{tabular}

Keterangan : ${ }^{*}=$ Signifikan pada $\alpha=0,05$

Selanjutnya hasil analisis pada tabel 1 di atas dapat diterjemahkan ke dalam diagram path sebagaimana dilihat pada gambar 1. Gambar path tersebut terlihat bahwa semua koefisien path dari variabel penyebab $X_{5}, X_{6}$ dan $X_{7}$ adalah bernilai positif serta pengaruh langsung dan tidak langsung ke variabel akibat $\mathrm{X}_{4}$ secara keseluruhan ternyata sebesar 46,214\% total variasi dari $X_{4}$ mampu dijelaskan oleh $X_{5}, X_{6}$ dan $X_{7}$

Model yang telah disepakati tersebut diperoleh hasil uji statistik yang disajikan pada tabel 1. Tabel tersebut memperlihatkan bahwa koefisien path dari variabel penyebab $X_{5}, X_{6}$ dan $X_{7}$. adalah signifikan baik secara keseluruhan maupun secara individual sehingga dapat diambil keputusan bahwa Ho ditolak dan $\mathrm{H}_{1}$ diterima. Ditolaknya Ho berarti hipotesis keempat yang menyatakan bahwa $X_{5}, X_{6}$ dan $X_{7}$ berpengaruh terhadap $X_{4}$, hal tersebut dapat diterima atau dibuktikan kebenarannya. 


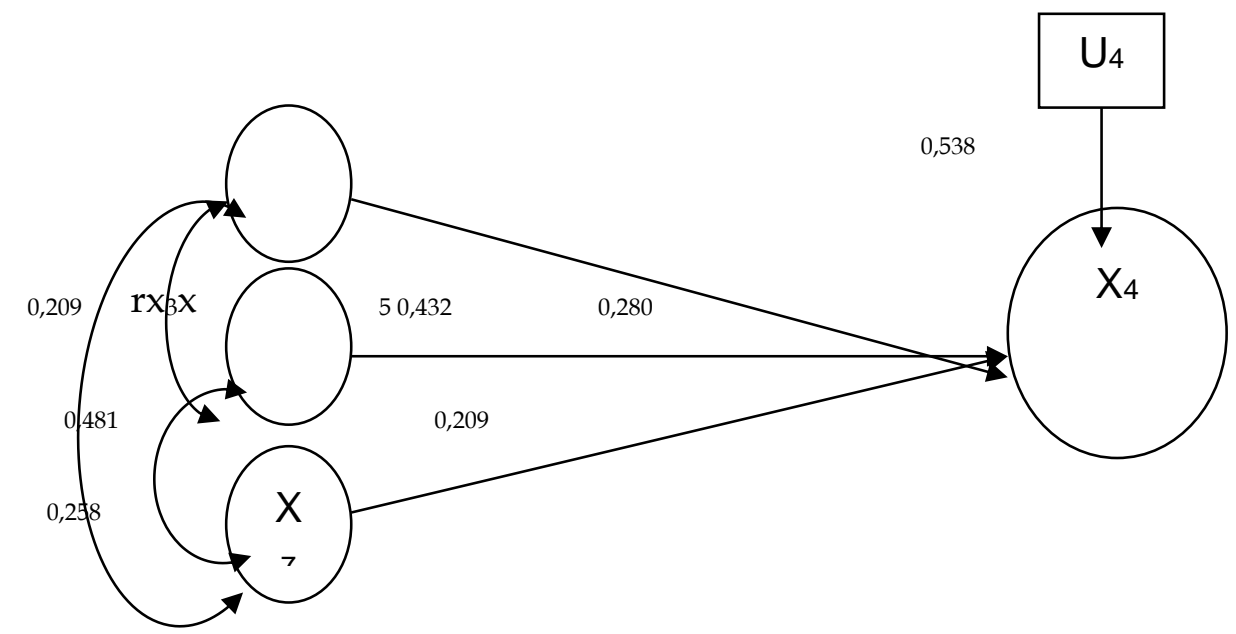

Gambar 1. Diagram Path hubungan antara variabel penyebab $X_{5}, X_{6}$ dan $X_{7}$. dengan variabel $\mathrm{X}_{4}$

Berdasarkan hasil pengujian statistik dan diagram path diatas, maka pengaruh variabel penyebab terhadap variabel akibat dapat diuraikan sebagai berikut :

\section{Bantuan Ternak $\left(X_{5}\right)$}

Bantuan Ternak $\left(X_{5}\right)$ berpengaruh nyata terhadap kewirausahaan anggota kelompok ternak binaan Putkati $\left(\mathrm{X}_{4}\right)$. Hal ini berarti bahwa kewirausahaan anggota kelompok tergantung pada bantuan ternak yang diberikan oleh Pemerintah, karena setiap anggota kelompok yang menerima bantuan ternak secara bergulir menumbuhkan semangat dan motivasi untuk berkelompok serta percaya diri melakukan berbagai kreativitas dalam kelompok. Hal ini sejalan yang dikemukakan oleh Chaplin (1968) mengatakan bahwa intensif berupa bantuan diarahkan sebagai suatu obyek eksternal yang cenderum membangkitkan motivasi dan menegakkan tingkah laku menuju pada sasaran. Melakukan kegiatan dalam kelompok selain memiliki kepercayaan diri, keinginan untuk belajar (Kwok dan See Ngoh, 1995) memilki komitmen terhadap tugas, juga berorientasi efisien, perhatian pada kualitas kerja.

\section{Kebijakan Pemerintah di bidang Pendampingan $\left(X_{6}\right)$}

Pendampinga $\left(\mathrm{X}_{6}\right)$ berpengaruh nyata terhadap kewirausahaan anggota kelompok ternak binaan Putkati $\left(X_{4}\right)$. Hal ini berarti bahwa kewirausahaan anggota kelompok tergantung pada pendampingan yang diberikan oleh Pemerintah, karena dengan adanya pendampingan maka anggota kelompok terbuka pemikirannya untuk lebih maju memperkuat kelembagaan kelompoknya, sebab kelompok yangmatang atau mandiri maka anggota kelompok tersebut lebih leluasa dan berani melakukan berbagai aktivitas, bimbingan, dan inovasi untuk mencapai skala usaha yang diharapkan. Hal ini sejalan yang 
dikemukakan oleh Anonim (2002) mengatakan bahwa hal-hal yang perlu difasilitasi oleh pendamping dalam membantu anggota kelompok mengembangkan usahanya yaitu : a) bimbingan untuk mencapai skala usaha, b) ketersediaan agro input dan permodalan, c) teknologi tepat guna yang sesuai dengan lokalita, d) homogenitas produk, e) kualitas yang terstandardisasi, dan $\mathrm{f}$ ) keteraturan produksi dan distribusi.

\section{Budaya Kebersamaan $\left(X_{7}\right)$}

Budaya kebersamaan $\left(X_{7}\right)$ berpengaruh nyata terhadap kewirausahaan anggota kelompok ternak binaan Putkati $\left(\mathrm{X}_{4}\right)$. Hal ini berarti bahwa kewirausahaan anggota kelompok tergantung pada budaya kebersamaan yang ada didaerah tersebut, karena dengan adanya budaya kebersamaan tersebut maka sikap kebersamaan dalam kelompok selalu terpelihara dan merupakan suatu aturan dalam kelompok, hal ini terlihat adanya ternak yang digulirkan kepada anggota baru, sehingga anggota kelompok tersebut selalu bertambah dalam memperkuat posisi kelembagaan atau kelompok ternak binaan Putkati di Sulawesi Selatan, dan ini merupakan suatu sistem nilai yang dapat diterima oleh anggota kelompok dan termasuk salah satu nilai kebersamaan yang perlu dilestarikan oleh setiap anggota kelompok. Hal ini sejalan yang dikemukakan oleh Widjaya (1986) mengatakan bahwa meskipun terjadinya modernisasi nilai kebersamaan dan norma sosial budaya lama akan tetap dapat diterima sepanjang memiliki keluesan dan dapat menyesuaikan diri dengan situasi dan kondisi yang selalu berubah dan berkembang. Lebih lanjut dikatakan bahwa budaya kebersamaan/ kegotongroyongan masyarakat atau anggota kelompok dapat mempengaruhi kegiatan usaha seseorang.

Untuk melihat mana yang paling berpengaruh diantara ketiga variabel penyebab tersebut, maka dapat dilihat padat 4.6 diatas, dimana variabel penyebab $\mathrm{X}_{6}(18,662 \%)$ lebih berpenbgaruh bila dibandingkan dengan variabel penyebab $X_{5}(7,840 \%)$, dan variabel $X_{7}$ $(4,368 \%)$. Hal ini berarti ada perbedaan pengaruh antara $X_{5}, X_{6}$, dan $X_{7}$ terhadap $X_{4}$. Hasil pengujian menunjukkan bahwa t.Hit $X_{6}(3,982), X_{5}(2,944)$ dan $X_{7}(2,335)>$ t.Tab $(1,967)$ ini berarti berpengaruh secara nyata (sigifikan)antara pendampingan, bantuan ternak dan budaya kebersamaan terhadap kewirausahaan anggota kelompok ternak binaan Putkati di Sulawesi Selatan.

Untuk mengetahui variabel penyebab mana yang memberikan pengaruh yang paling dominan dalam menentukan peningkatan $\mathrm{X}_{4}$ dapat dilihat dari besar sumbangan pengaruh 
( Total pengaruh) yang diberikan oleh masing-masing variabel penyebab sebagai mana disajikan pada Tabel 2.

Tabel 2. Sumbangan Pengaruh Variabel Penyebab $X_{5}, X_{6}$ dan $X_{7}$ Terhadap Variabel akibat $\mathrm{X}_{4}$

\begin{tabular}{|c|c|c|c|c|c|}
\hline \multirow{2}{*}{$\begin{array}{l}\text { Variabel } \\
\text { Penyebab }\end{array}$} & \multicolumn{4}{|c|}{ Sumbangan Langsung Ke (\%) } & \multirow[t]{2}{*}{ Total (\%) } \\
\hline & Langsung & Via $X_{5}$ & Via $X_{6}$ & Via $X_{7}$ & \\
\hline$X_{5}$ & 7,840 & - & 2,528 & 2,815 & 13,183 \\
\hline$X_{6}$ & 18,662 & 2,528 & - & 2,329 & 23,529 \\
\hline$X_{7}$ & 4,368 & 2,815 & 2,329 & - & 9,512 \\
\hline
\end{tabular}

Dari hasil analisis Tabel 2. tersebut diatas, menunjukkan bahwa besarnya sumbangan pengaruh yang diberikan oleh variabel $\mathrm{X}_{6}(23,529 \%)$ adalah relatif lebih basar dibandingkan dengan sumbangan pengaruh yang diberikan oleh variabel $X_{5}(13,183 \%)$ dan variabel $X_{7}$ (9,512\%). Dengan demikian meskipun perbedaan pengaruh tidak terlalu besar antara pendampingan dengan bantuan ternak dan budaya kebersamaan terhadap kewirausahaan anggota kelompok ternak binaan Putkati, namun pendampingan cenderung lebih dominan dalam menentukan kewirausahaan anggota kelompok ternak binaan Putkati di Sulawesi selatan.

\section{KESIMPULAN}

Berdasarkan analisis dan pembahasan hasil penelitian maka dapat disimpulkan bahwa bantuan ternak, pendampingan dan budaya kebersamaan berpengaruh terhadap kewirausahaan anggota kelompok ternak binaan Putkati di Sulawesi Selatan. Sedangkan kontribusi yang paling dominan atau terbesar pengaruhnya adalah pendampingan/konsultan. Dalam upaya mengembangkan kelompok ternak binaan Putkati di Sulawesi Selatan, maka disarankan kepada pemerintah atau instansi terkait bahwa dalam pembentukan kelompok sebaiknya pada anggota masyarakat tani yang memiliki jiwa wirausaha yang kuat, sehingga kelompok dapat berkembang dengan baik. 


\section{DAFTAR PUSTAKA}

Anonim. 2002. Pembinaan dan Pengembangan Kelompok Tani Proyek Putkati. Departemen Pertanian, Direkturat Jenderal Produksi Peternakan. Proyek Pengembangan Usaha Tani Terpadu Kawasan Indonesia Timur.

Chaplin, J. P. 1968. Kamus lengkap Psikologi. PT. Rajagrafindo Persada, Jakarta.

Kwok, B, C. and See Ngoh, C.C. 1995. Steeping Out. The Making of Chinese Entrepreneurs. Prentice-Hall Inc., New York.

Widjaya, A. W. 1986. Manusia Indonesia. Individu, Keluarga dan Masyarakat, Topik-topik Kumpulan Bahan Bacaan Mata Kuliah Ilmu Sosial Dasar. CV. Akademika Pressindo, Jakarta. 